\title{
Prenatal diagnosis of an isolated thrombus in fetal IVC
}

\author{
Momina Zulfeen 지 , ${ }^{1,2}$ Tatiana Freire-Lizama, ${ }^{3}$ Mike Berry ${ }^{3}$
}

'ObGyn, University of Toronto, Toronto, Ontario, Canada ${ }^{2}$ ObGyn, Kasturba Medical College Manipal, Manipal, Karnataka, India ${ }^{3}$ Maternal Fetal Medicine, University of Toronto, Toronto, Ontario, Canada

\section{Correspondence to}

Dr Momina Zulfeen; mominazulfeen@gmail.com

Accepted 16 July 2021

\section{DESCRIPTION}

A healthy 27-year-old primigravida of middle eastern ethnicity presented for prenatal care after arriving in Canada in the early second trimester. Anatomy scan at 20 weeks was normal, and gestational diabetes was diagnosed on routine screening. Glycaemic control was poor, requiring significant doses of insulin.

On growth and well-being scan at 37 weeks gestation, a tubular echogenic lesion (figure 1 and video 1) was identified in the inferior vena cava (IVC). There was no polyhydramnios, and fetal growth was appropriate for gestational age. No ascites or hydropic features were noted. Ductus venosus waveform appeared normal, with no evidence of heart failure. Based on the appearance and echogenicity, the lesion was felt to be a vascular thrombus, but it appeared to be isolated to the fetal IVC, without evidence of hepatic or renal involvement. Viral serologies were negative for cytomegalovirus and toxoplasmosis.

In consultation with neonatology, the patient was consented for induction of labour, given a term gestation, poor glycaemic control, and a suspected fetal vascular thrombus. Labour progressed normally and resulted in spontaneous delivery of a live infant with normal Apgars. Postnatally, neonatal hypoglycaemic required intravenous fluids and observation. Neonatal ultrasound confirmed an IVC thrombus. D-dimers were elevated. Workup was negative for thrombophilia, and platelets remained within normal limits. The newborn was managed conservatively due to the concurrent presence of a small intracranial haemorrhage. Over the next 2 weeks, ultrasound identified progression of

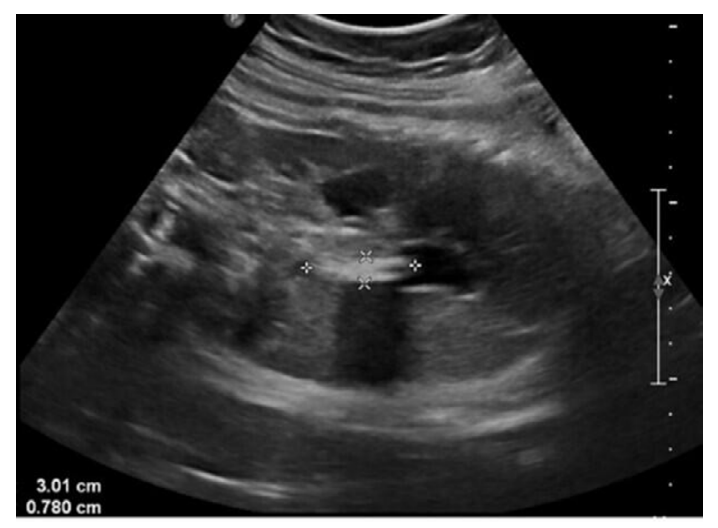

Figure 1 In oblique sagittal view along the long axis of inferior vena cava (IVC), an elongated echogenic lesion of 3 * $0.8 \mathrm{~cm}$ (orange arrow) is seen in the IVC, consistent with intravascular thrombus.

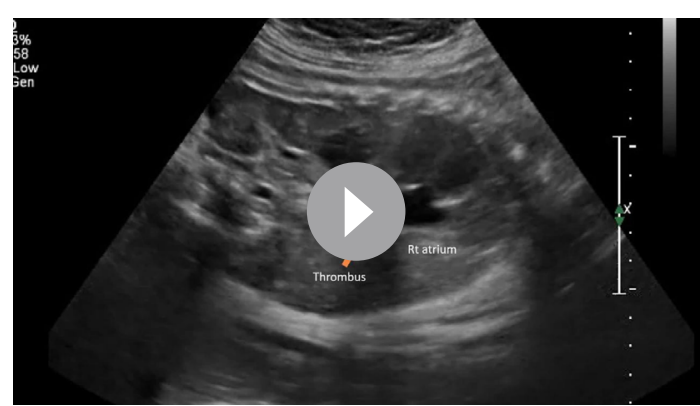

Video 1 Ultrasound image and cine clip showing fetal IVC lesion.

the thrombus to the hepatic vein and right renal vein. Follow-up ultrasounds, however, showed recanalisation and complete resolution of hepatic and renal vein thrombosis (RVT). There was a persistent IVC calcified thrombus. At 8 months of age, the child remains asymptomatic with good interval renal growth.

Most cases of intra-abdominal venous thrombosis are diagnosed shortly after birth. Prenatal diagnosis of thrombosis is rare. Case reports are confined to RVT, some with involvement of the IVC. ${ }^{1}$ Mean gestational age at diagnosis is 32 weeks, with reported $63 \%$ mortality. ${ }^{2}$ IVC thrombus was reported only in severe cases, representing later stages of disease, with obstructive consequences such as cardiac failure. To our knowledge, an isolated IVC thrombus with postnatal progression to RVT postnatally has never been described in the literature.

Foetal thrombosis can be idiopathic; however, fetal hypercoagulable states have been described in association with acquired conditions such as fetal hypoxia and maternal diabetes, or congenital thrombophilia. It is noteworthy that 5 out of 25 cases reported occurred in the setting of maternal diabetes. $^{2}$ Reported management varies, with conservative management described for unilateral

\section{Patient's perspective}

Our patient expressed her concerns over lack of prognostic information at the time of diagnosis. For our patient, receiving care in a foreign country added to this anxiety.

The couple eventually reflected on the whole experience as 'well supported and satisfying' and were happy with the outcome. Our patient hopes "this case report will further our information on this condition and help moms like (her)". 
RVT, and expedited delivery indicated for bilateral RVT or IVC thrombus, evidence of fetal distress and hydrops. ${ }^{13}$

Our presentation brings to light a unique case of isolated prenatal IVC thrombosis associated with maternal diabetes. The occurrence of IVC thrombus in the absence of RVT could suggest a stronger correlation between fetal hypercoagulability and maternal diabetes. As screening for fetal thrombosis is not

\section{Learning points}

Prenatal diagnosis of fetal thrombosis is rare; in most cases, no identifiable cause is found. Maternal diabetes appears to be a risk factor.

- Rarely, a fetal inferior vena cava (IVC) thrombus can present in the absence of fetal renal vein thrombosis (RVT) or hepatic vein thrombosis, and can progress postnatally. In cases where the newborn is stable, conservative management may be successful.

- Diagnosis of fetal IVC thrombus or bilateral RVT thrombus should prompt discussion with neonatology, close fetal surveillance and consideration of expedited delivery. part of routine ultrasound follow-up, this possibility may be considered in women with poor glycaemic control.

Twitter Momina Zulfeen @dr_zulf

Contributors All authors contributed to the writing of the manuscript. TF overviewed the manuscript and was the primary investigator.

Funding The authors have not declared a specific grant for this research from any funding agency in the public, commercial or not-for-profit sectors.

Competing interests None declared.

Patient consent for publication Obtained.

Provenance and peer review Not commissioned; externally peer reviewed.

\section{ORCID iD}

Momina Zulfeen http://orcid.org/0000-0003-2767-2192

\section{REFERENCES}

1 Smorgick N, Herman A, Wiener Y, et al. Prenatal thrombosis of the inferior vena cava and the renal veins. Prenat Diagn 2007;27:603-7.

2 Moaddab A, Shamshirsaz AA, Ruano R, et al. Prenatal diagnosis of renal vein thrombosis: a case report and literature review. Fetal Diagn Ther 2016;39:228-33.

3 Hage ML, Liu R, Marcheschi DG, et al. Fetal renal vein thrombosis, hydrops fetalis, and maternal lupus anticoagulant. A case report. Prenat Diagn 1994;14:873-7.

Copyright 2021 BMJ Publishing Group. All rights reserved. For permission to reuse any of this content visit

https://www.bmj.com/company/products-services/rights-and-licensing/permissions/

BMJ Case Report Fellows may re-use this article for personal use and teaching without any further permission.

Become a Fellow of BMJ Case Reports today and you can:

- Submit as many cases as you like

- Enjoy fast sympathetic peer review and rapid publication of accepted articles

- Access all the published articles

Re-use any of the published material for personal use and teaching without further permission

Customer Service

If you have any further queries about your subscription, please contact our customer services team on +44 (0) 2071111105 or via email at support@bmj.com.

Visit casereports.bmj.com for more articles like this and to become a Fellow 